p-ISSN: 1411-4348, e-ISSN: 2541-4577

\title{
PENGARUH KOMPOSISI KOMPON BAN DENGAN BATIKAN MIRING TERHADAP KOEFISIEN GRIP BAN PADA LINTASAN ASPAL PADA KONDISI BASAH DAN KERING
}

\author{
Pramuko Ilmu Purboputro, Muh.Alfatih Hendrawan \\ Jurusan Teknik Mesin Universitas Muhammadiyah Surakarta \\ J1. A. Yani Tromol Pos I Pabelan, Kartosuro \\ email :pip272@ums.id
}

\begin{abstract}
ABSTRAK
Penelitian ini adalah penelitian awal yang bertujuan yang pada akhirnya untuk mendapatkan koefisien grip. Penelitian ini untuk mendapatkan kompossisi bahan yang tepat untuk bahan karet luar ban dan penelitian dilanjutkan untuk mendapatkan angka koefisien cengeram (grip) ban pada batikan panah.

Metoda yang dilakukan adalah dengan mencampur komponen ban, dengan komposisi yang berbeda. Spesimen tersebut kemudian dilakukan percobaan kekerasan shore dan percobaan keausan. Hasil yang didapat dibandingkan bahan kompon yang sudah ada di pasaran.

Dari penelitian ini didapat kompon variasi 1 dengan komposisi 30\% carbon black dan $2 \%$ sulfur dari jumlah seluruh komposisi kompon, menghasilkan harga koefisien grip sebesar 0,761 kondisi lintasan kering dan 0,718 pada kondisi lintasan basah. Selain itu, penambahan carbon black dan sulfur juga berpengaruh pada kekerasan. Pada pengujian shore A terbesar pada kompon variasi 3 sebesar 71,17 dengan komposisi $33 \%$ carbon black dan 2,2\% sulfur.
\end{abstract}

Kata kunci: komposit karet, bahan ban luar, kekerasan, keausan.

\begin{abstract}
This study is a preliminary research aimed to obtain grip coefficients. This research objective is to get the right material compositions for tire rubber material and it is continued to get the coefficient of grip of tire on the arrow batik.

The used method was mixing the tire components with different compositions. The specimens subjected to shore hardness experiments and wear and tear experiments. The obtained results were compared to the compound materials that already exist in the market.

From this research, it can be showed that the compound of variation with the composition of $30 \%$ carbon black and $2 \%$ sulfur from the total composition of the compound resulted in grip coefficient value of 0.761 on dry track conditions and 0.718 on wet track conditions. In addition, black and sulfur carbon enhancers also have an effect on hardness. In shore A test, the largest hardness is 71.17 on compound variation 3 with a composition of 33\% carbon black and $2.2 \%$ sulfur.
\end{abstract}

Keywords: rubber composite, tire material, hardness, wear and tear. 


\section{PENDAHULUAN}

Komposisi bahan adalah yang paling berpengaruh langsung terhadap kualitas yang akan dihasilkan. Sampai saat ini karet masih unsur utama dari sebuah ban. Hampir semua ban merupakan produk karet. Ini karena bahan karet tidak cepat menyerap panas. Bahan utama yang digunakan untuk pembuatan ban ini terdiri dari kawat untuk tepi ban (mempengaruhi grip ban. Jenis jalan aspal, semen, batu dank ondisi jalan bead wire), kain ban (terbuat dari tekstile dan jalinan kawat baja), tepung karbon (carbon black), sulfur (belerang) dan kompon. (Wikipedia, 2012).

Menurut Abednego (1979) kompon karet adalah campuran karet mentah dengan bahanbahan kimia yang belum divulkanisasi. Proses pembuatan kompon adalah pencampuran antara karet mentah dengan bahan kimia karet (bahan aditif). Karet sintetis adalah karet yang berasal dari hasil samping pengolahan minyak bumi yang kemudian melalui reaksi polimerisasi menjadi suatu material baru yang sifatnya mendekati sifat karet alam. Bahan kimia yang digunakan untuk meningkatkan sifat fisis karet dalam pembuatan kompon adalah bahan anti degrandan, filler (bahan pengisi), Anti oksidan, bahan pelunak dan bahan kimia lainnya. Ban kendaraan terbuat dari karet karena sifatnya yang lentur dan elastis. Elastis adalah keadaan benda dimana jika ditekan akan kembali ke bentuk semula.

\section{TUJUAN PENELITIAN}

Dalam penelitian ini yaitu mengolah karet alam dicampur dengan bahan-bahan pendukung lainnya dengan beberapa variasi perbandingan komposisi untuk membuat lapisan ban luar dengan tujuan, diantaranya:

1. Mempelajari pengaruh komposisi kompon pada koefisien grip dengan lintasan aspal dalam kondisi basah dan kering dengan batikan panah.

2. Mempelajari perbandingkan hasil pengujian kekerasan dan keausan bahan ban antara variasi kompon buatan dengan kompon dipasaran pada lintasan Aspal

\section{MANFAAT PENELITIAN}

Penelitian ini dilakukan dengan maksud untuk :

1. Mengetahui cara dan bahan dalam pembuatan kompon ban.

2. Mengetahui campuran komposisi kompon yang tepat untuk mendapatkan koefisien grip ban yang baik, dari penelitian kekerasan dan keausannya.

3. Mengetahui perbandingan dari berbagai variasi komposisi kompon untuk koefisien grip pada lintasan aspal dalam kondisi kering dan basah.

\section{TINJAUAN PUSTAKA}

Penelitian terdahulu yang pernah dilakukan dalam bidang kompon telah mengungkapkan bahwa penggunaan belerang 30-50 phr secara garis besar dapat menaikkan tegangan putus dan kekerasan karet ebonit. Sedangkan penggunaan riklim sampai dengan $40 \mathrm{phr}$ atau perbandingan RSS sampai dengan 60/40 dapat meningkatkan sifat tegangan putus dan kekerasan karet ebonit. Baik penggunaan belerang 30-50 phr maupun penggunaan riklim 2040 menghasilkan perpanjangan putus yang tetap. Komposisi karet ebonit optimum dicapai pada penggunaan belerang 30phr. Dengan ini maka semakin tinggi prosentase penambahan beleran akan mengakibatkan peningkatan sifat tegangan putus dan kekerasan pada karet ebonit (Setyowati, dkk, 2004).

Grip dapat ditingkatkan dengan dua cara yaitu meningkatkan gaya vertikal dan meningatkan koefisien gesek antara ban dan aspal. Karena permukaan aspal adalah besaran konstan yang tidak bisa diubah, satu-satunya cara memperbaiki koefisien gesek adalah dengan mempebaiki kualitas kompon ban. Koefisien gesek kompon ban ini fungsi dari temperatur. 
Kondisi terbaik biasanya dicapai kompon ban pada temperatur antara $85^{\circ} \mathrm{C}$ sampai $100^{\circ} \mathrm{C}$. Kualitas kompon juga tergantung dari jenis karetnya. Semakin keras kompon biasanya kualitas gripnya menurun, tetapi ketahanan terhadap ausnya meningkat. Kondisi ideal tentu saja apabila para pabrikan ban bisa membuat kompon yang keras tetapi mempunyai grip yang baik. (Daroyni roy,2008).

Amraini, dkk (2009). Judul penelitiannya "Pengaruh Filler Carbon Black Terhadap Sifat dan Morfologi Komposit Natural Rubber/Polypropylene". Penelitian ini mempelajari pengaruh komposisi dan teknik penambahan filler carbon black (CB) terhadap sifat tensile dan morfologi dalam campuran natural rubber/polypropylene (NR/PP). Hasil yang didapat adalah penggunaan Two Roll-Mixer dapat meningkatkan sifat tensile campuran NR/PP. Kesamaan dengan peneliti adalah pada alat yang digunakan yaitu peralatan untuk pembuatan kompon karet, yaitu Two-roll Mixing Mill. Kesamaan bahan yang dipakai adalah penggunaan karet alam. Karet alam yang digunakan pada penelitian ini adalah jenis SIR-20 dengan Money Viscosity 70 pada $100^{\circ} \mathrm{C}$. Sedangkan penulis karet alamnya adalah natural rubber jenis RSS. filler CB dimana CB dan NR dicampur terlebih dahulu.

Dalam penelitian ini dibutuhkan variasi komposisi kompon yang dipadukan dengan sulfur dan karbon hitam untuk memperoleh hasil yang diinginkan. (Riyadhi Adi, 2008) maka untuk menaikkan koefisien gesek dengan memperbaiki kualitas dari komposisi kompon ban. Dalam penelitian ini dibutuhkan variasi komposisi kompon yang dipadukan dengan sulfur dan karbon hitam untuk memperoleh hasil yang diinginkan. (Riyadhi Adi, 2008)

\section{METODOLOGI PENELITIAN}

Diagram alir penelitian

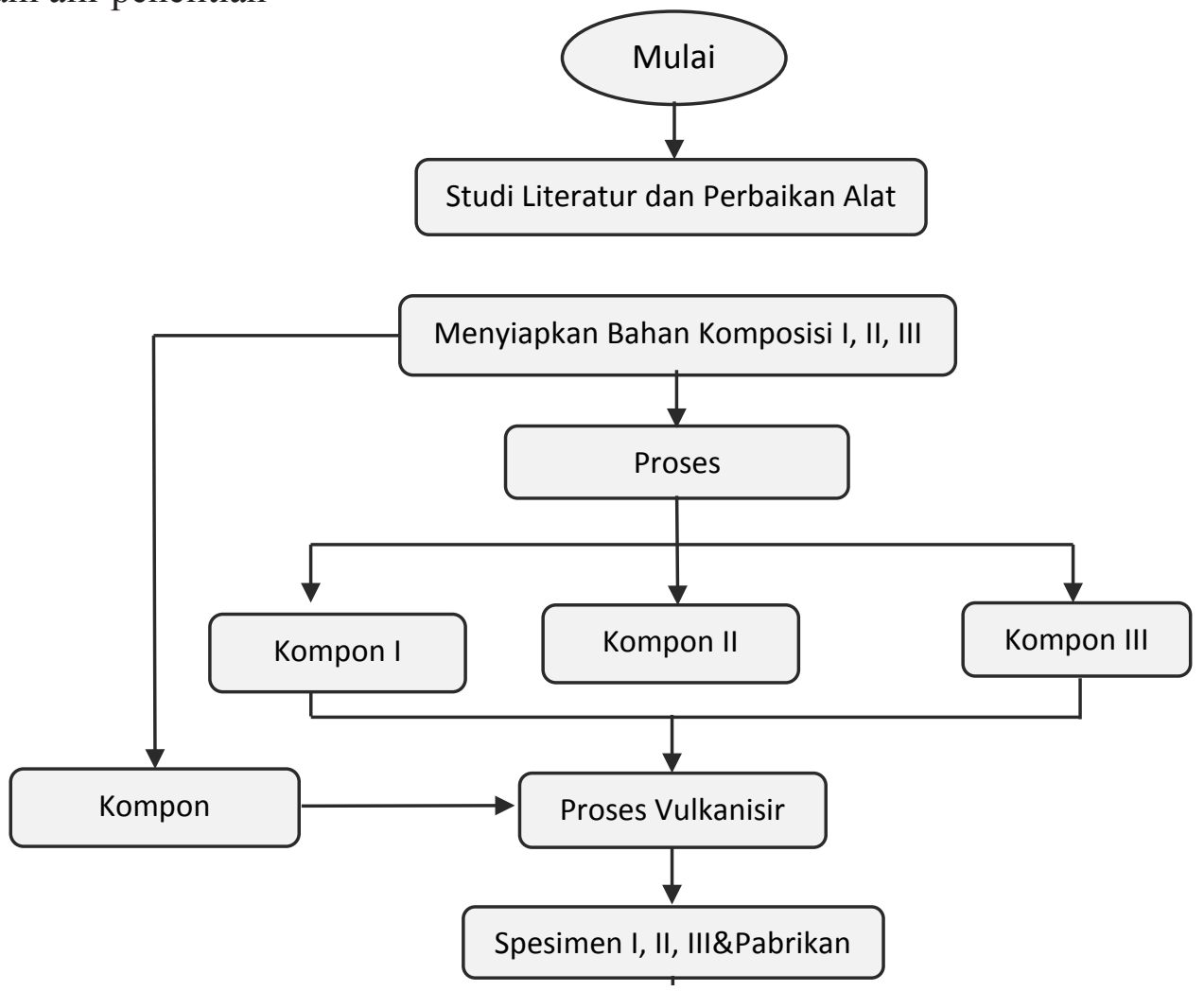




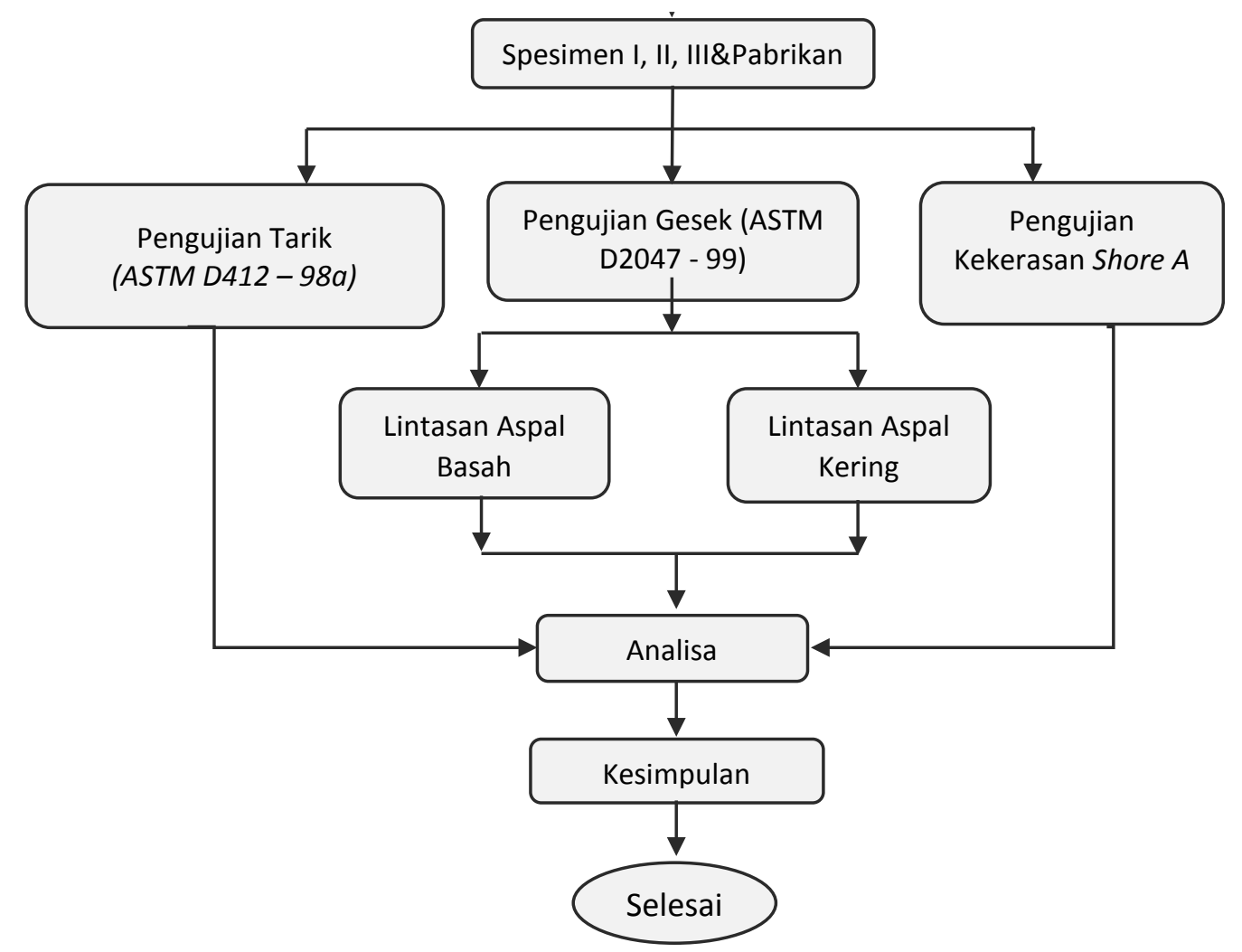

Gambar 1. Skema Diagram Alir Penelitia

\section{HASIL DAN PEMBAHASAN \\ Hasil Pengujian \\ Hasil Studi Uji Kekerasan rata - rata}

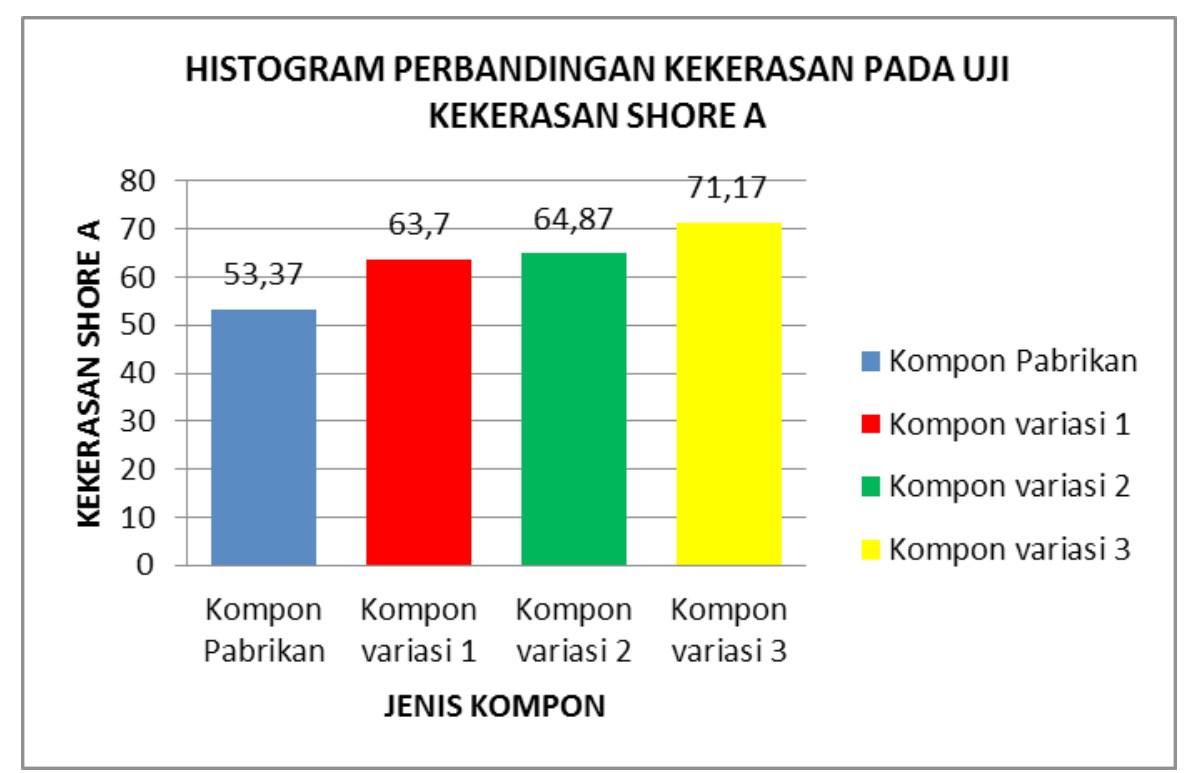

Gambar 2. Histogram antara jenis kompon dan nilai kekerasan Shore A

Histogram perbandingan Jenis kompon terhadap nilai kekerasan Shore A dengan Standart metoda uji SNI. 0778 - 2009, butir 6.2.2. Didapatkan hasil studi sebagai berikut : nilai kekerasan untuk Kompon Pabrikan sebesar 53.37, nilai kekerasan Kompon variasi 1 sebesar 63.7, nilai kekerasan Kompon variasi 2 sebesar 64.87 dan nilai kekerasan kompon 
variasi 3 sebesar 71.17. Maka dari hasil tersebut dapat disimpulkan bahwa kompon buatan 1,2 dan 3 memiliki nilai kekerasan diatas kompon pabrikan.

Dilihat dari besarnya kekerasan shore A, kompon variasi 3 memiliki kekerasan yang paling tinggi, karena penggunaan carbon black yang lebih banyak sebagai bahan pengisi berperan penting pada kekerasan dan keuletan. Boonstra, 2005 menjelaskan bahwa carbon black dapat memperbesar volume karet, memperbaiki sifat fisis karet dan memperkuat vulkanisasi.Selain itu, penggunaan sulfur juga mempengaruhi kekerasan kompon.Hal ini sesuai dengan percobaan yang dilakukan Rahmaniar dkk. Penggunaan sulfur yang tepat akan menghasilkan kekerasan yang tinggi sesuai kebutuhan.

\section{Hasil Uji Tarik}

Pada gambar 3, hasil uji tarik kompon pabrikan didapatkan nilai sebesar 253,72 kgf/ cm2,komponvariasi buatan 1 memiliki tegangan tarik dengan nilai 178,84 kgf $/ \mathrm{cm} 2$, kompon variasi buatan 2 memiliki tegangan tarik dengan nilai 159,47 kgf/cm2,kompon variasi buatan 3 memiliki tegangan tarik dengan nilai $130,49 \mathrm{kgf} / \mathrm{cm} 2$.

Dengan demikian dapat kita simpulkan dari pengujian tarik kompon variasi buatan No. 1,2,3 dan kompon pabrikan untuk nilai tegangan tarik rata-rata tertinggi dimiliki kompon pabrikan dengan tegangan tarik sebesar $253,72 \mathrm{kgf} / \mathrm{cm} 2$ sedangkan untuk kompon variasi buatan yang memiliki tegangan tarik tertinggi yaitu kompon variasi buatan No.1 dengan nilai 178,84 kgf/cm2 dan tegangan tarik yang terendah adalah kompon variasi buatan No.3 dengan nilai 130,49 kgf/cm2 jadi kompon buatan yang mendekati nilai tegangan tarik dengan kompon pabrikan yaitu kompon variasi buatan No.1 dengan nilai tegangan tarik $178,84 \mathrm{kgf} / \mathrm{cm} 2$.Penambahan filler black carbon secara siknifikan dapat meningkatkan sifat tensil, hasil didukung penelitian sebelumnya oleh Amraini, dkk (2009) dengan judul penelitiannya "Pengaruh Filler Carbon Black Terhadap Sifat dan Morfologi Komposit Natural Rubber/Polypropylene".

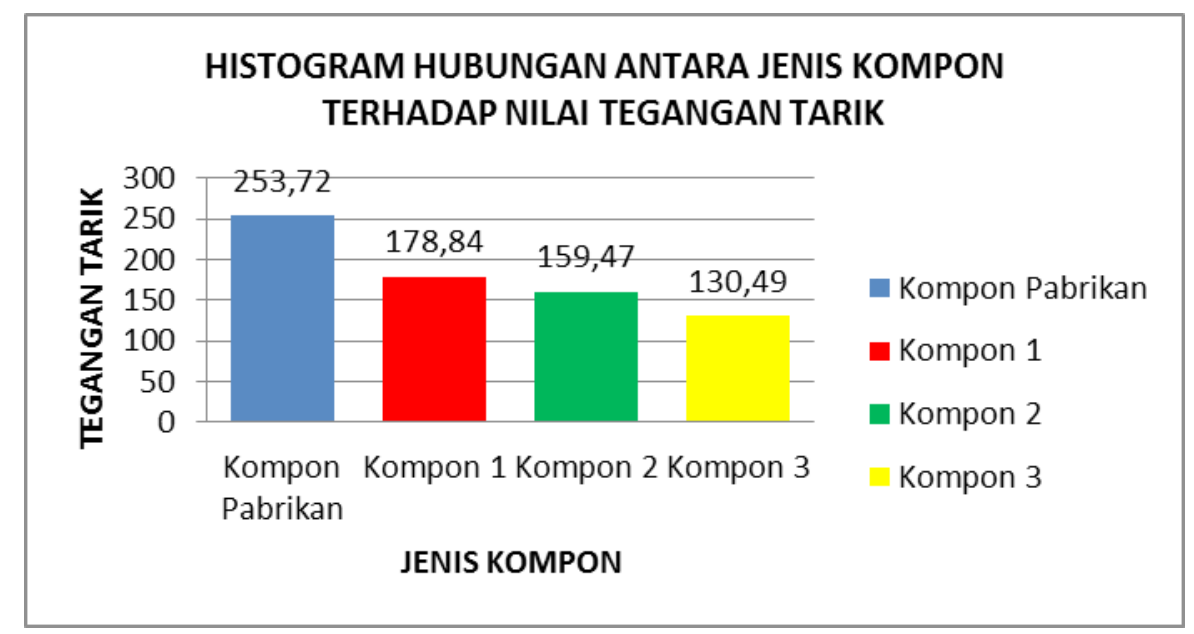

Gambar 3. Histogram Hubungan Antara Jenis Kompon terhadap Nilai Beban Tarik

\section{Hasil Uji Gesekan pada Aspal \\ Hasil Perhitungan Volume Keausan}

Di bawah ini merupakan tabel yang memuat data tingkat keausan produk kompon yang telah dilakukan pengujian gesek pada lintasan aspal dalam kondisi lintasan kering 


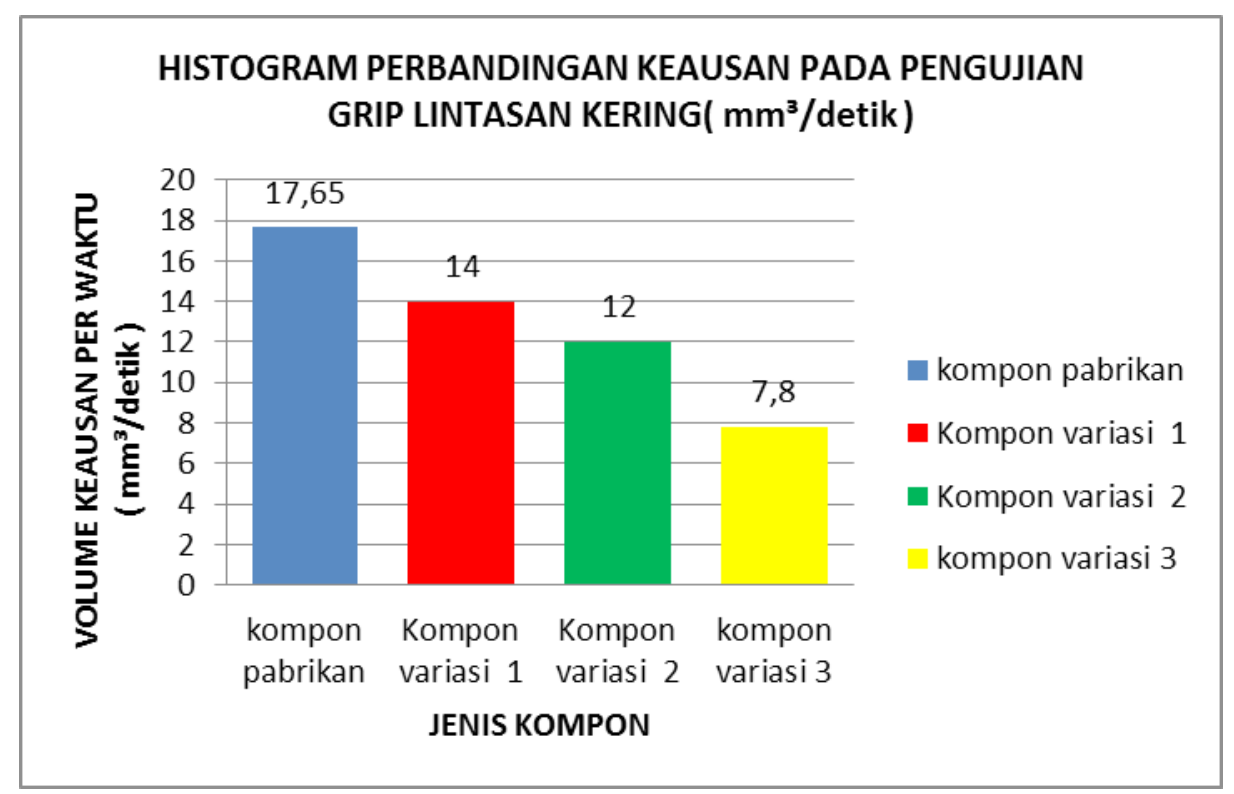

Gambar 4. Histogram hubungan jenis kompon terhadap kKeausan rata-rata pada kondisi kering

Pada pengujian grip lintasan kering, kompon pabrikan memiliki nilai keausan lebih tinggi yaitu 17,65 mm3/detik. Pada pengujian yang sama, kompon variasi 1 dan kompon variasi 2 memiliki nilai keausan dibawah kompon pabrikan yaitu masing - masing $14 \mathrm{~mm} 3$ / detik dan $12 \mathrm{~mm} 3 /$ detik. Sedangkan kompon variasi 3 memiliki nilai keausan yang paling rendah dari kompon pabrikan yaitu 7,8 $\mathrm{mm} 3 /$ detik.

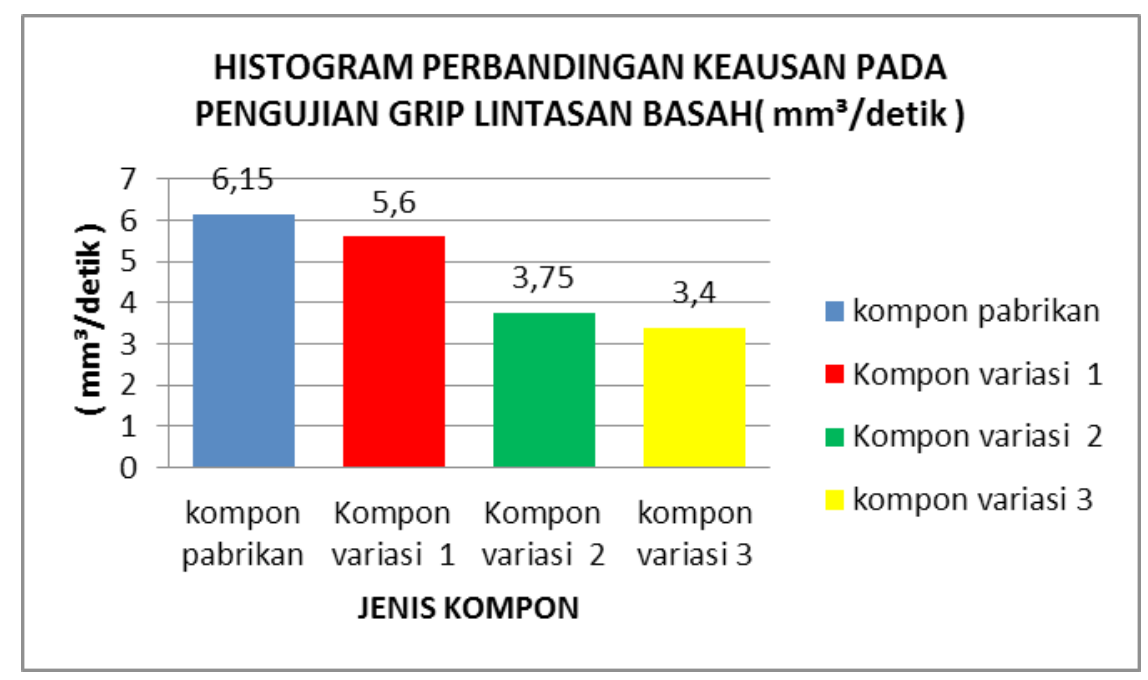

Gambar 5. Histogram hubungan jenis kompon dengan Keausan rata-rata pada kondisi basah

Pada pengujian grip lintasan basah, kompon pabrikan memiliki nilai keausan lebih tinggi yaitu 6,15 mm3/detik. Pada pengujian yang sama, kompon variasi 1 memiliki nilai keausan yang rendah yaitu 5,6 mm3/detik. Sedangkan kompon variasi 2dan kompon 3 memiliki nilai keausan yang hampir sama yaitu masing masing 3,75 mm3/detik dan 3,4 mm3/detik.

\section{KESIMPULAN}

Dari studi yang dilakukan penulis dapat menarik kesimpulan, yaitu :

1. Penambahan carbon black dan sulfur pada spesimen kompon mengalami perubahan terhadap koefisien grip ban. Pada kompon variasi 1 dengan komposisi 30\% carbon black 
dan 2\% sulfur dari jumlah seluruh komposisi kompon, menghasilkan harga koefisien grip sebesar 0,761 kondisi lintasan kering dan 0,718 pada kondisi lintasan basah. Selain itu, penambahancarbon black dan sulfur juga berpengaruh pada kekerasan. Pada pengujian shore A terbesar pada kompon variasi 3 sebesar 71,17 dengan komposisi 33\% carbon black dan 2,2\% sulfur.

2. Pada pengujian grip kering dan basah, dari ketiga variasi kompon didapatkan harga koefisien grip tertinggi pada kompon variasi 1 dan terendah pada kompon variasi 3 . Koefisien grip yang terjadi pada pengujian lintasan aspal basah lebih rendah dibandingkan dengan kondisi lintasan kering, hal ini disebabkan ada lapisan air pada kedua sisi yang bergesekan sehingga mempengaruhi suhu dan mengurangi daya rekat kompon terhadap lintasan.

\section{DAFTAR PUSTAKA}

[1] Anonim.,Sejarah karet alam di Indonesia. Diakses tanggal_18 juli 2013 jam 18.30 wib dari: http://indonesian natural rubber.blogspot.com/2011/02/sejarah-karet-alam-diindonesia.html

[2] Anonim.,Jenis-jenis karet. Diakses tanggal 18 juli 2013 jam 18.40 wib dari: http:// indonesian natural rubber.blogspot.com/2011/02/jenis-jenis-karet.html

[3] Anonim., 2011.Perkembangan karet sintetis. Diakses tanggal 18 juli 2013 jam 18.45 wib dari: http://indonesian natural rubber.blogspot.com/2011/02/perkembangan-karetsintetis.html

[4] Ciesielski, Andrew., 1999. An Introduction to Rubber Technology. Rapra Tecnology Limited, hal 31-56. Diakses tanggal 12 oktober 2013 jam 21.10 wib dari http://www. rapra.net

[5] Riyadhi, Adi.,2008. Vulkanisasi karet. Diakses tanggal20 juli 2013 jam 19.15 dari: http://www.chem-is-try.org/artikel_kimia/kimia_material/vulkanisasi_karet/

[6] Sasongko, Atur R., 2012. Studi pengaruh ukuran partikel dan jumlah phr carbon black sebagai bahan pengisi terhadap sifat mekanik produk karet alam. Universitas Indonesia. 